fournal of Medical Genetics (1971). 8, 315.

\title{
Distribution of ABO Blood Groups, G6PD Deficiency, and Abnormal Haemoglobins in Leprosy
}

\author{
N. SAHA, H. B. WONG, B. BANERJEE, and M. O. WONG \\ From the Departments of Physiology and Paediatrics, Faculty of Medicine, University of Singapore, \\ and the Trafalgar Home, Singapore
}

The extensive literature on the association of $\mathrm{ABO}$ blood groups and leprosy has been reviewed by Salzano (1967). He listed 27 series and reported an apparent excess of blood group $O$ and a lack of $B$ among leprosy patients compared to normal controls. In his list the highest level of significant association was observed in Japanese patients. Among the Japanese workers, Omichi (1928) did not find any association whereas Hasegawa (1937) observed a higher frequency of B and Sato (1949) a lower frequency of $B$ among leprosy patients compared to $O$ groups. In the remaining 24 in the series listed by Salzano there was hardly any O:B association. Recently Vogel (1970) calculated the association levels of ABO blood groups in leprosy from 33 published series and reported an O:A association $(\mathrm{P} \leq 0.0027)$.

In an earlier analysis of genetic association in pulmonary tuberculosis (Saha and Banerjee, 1968) the authors could find a significant association only in the case of Chinese patients, and it has been suggested that the question of genetic association may further be complicated by an ethnic factor.

In view of the limited and controversial literature of the association of ABO blood groups in Japanese leprosy patients, we thought it worthwhile to examine the question of $\mathrm{ABO}$ association in another Mongolian race, namely the Chinese.

It has been reported that there is a higher incidence of G6PD deficiency among lepers (Kher and Grover, 1969). We thought it worthwhile to verify this in a Chinese population and also to study the incidence of abnormal haemoglobins in lepers compared to healthy subjects.

\section{Materials and Methods}

All the 459 Chinese ward patients of both sexes at the Trafalgar Home, Singapore which is the only leprosarium in the Republic, were investigated for the

Received 7 December 1970. distribution of ABO blood groups, G6PD deficiency and abnormal haemoglobins. The details of the method have been published elsewhere (Saha and Banerjee, 1968; Saha, 1969 and 1970). The Chinese control series of pulmonary tuberculosis was used as the control series for the present study.

\section{Results and Discussion}

The results are presented in the Table, which shows the distribution of $\mathrm{ABO}$ blood groups in leprosy patients and in the control group.

TABLE

DISTRIBUTION OF ABO BLOOD GROUPS IN PATIENTS WITH LEPROSY COMPARED TO NORMAL CONTROL

\begin{tabular}{|c|c|c|c|c|c|c|c|c|}
\hline \multirow{3}{*}{$\begin{array}{l}\text { Blood } \\
\text { Groups }\end{array}$} & \multicolumn{2}{|c|}{ Controls* } & \multicolumn{6}{|c|}{ Leprosy Patients } \\
\hline & \multirow[t]{2}{*}{ No. } & \multirow[t]{2}{*}{$\%$} & \multicolumn{2}{|c|}{$\begin{array}{l}\text { Lepro- } \\
\text { matous }\end{array}$} & \multicolumn{2}{|c|}{$\begin{array}{l}\text { Non- } \\
\text { lepro- } \\
\text { matous }\end{array}$} & \multicolumn{2}{|c|}{ Total } \\
\hline & & & No. & $\%$ & No. & $\%$ & No. & $\%$ \\
\hline $\begin{array}{c}\mathbf{O} \\
\mathbf{A} \\
\mathbf{B} \\
\mathbf{A B} \\
\text { Total }\end{array}$ & \begin{tabular}{|r|}
6644 \\
3967 \\
3814 \\
837 \\
15,261
\end{tabular} & $\begin{array}{r}43.5 \\
26.0 \\
25 \cdot 0 \\
5.5\end{array}$ & $\begin{array}{r}140 \\
87 \\
93 \\
18 \\
338\end{array}$ & $\begin{array}{r}41 \cdot 4 \\
25 \cdot 7 \\
27 \cdot 5 \\
5 \cdot 3\end{array}$ & $\begin{array}{r}46 \\
33 \\
35 \\
7 \\
121\end{array}$ & $\begin{array}{r}38 \cdot 0 \\
27 \cdot 3 \\
28 \cdot 9 \\
5 \cdot 8\end{array}$ & $\begin{array}{r}186 \\
120 \\
128 \\
25 \\
459\end{array}$ & $\begin{array}{r}40 \cdot 5 \\
26 \cdot 1 \\
27 \cdot 9 \\
5 \cdot 4\end{array}$ \\
\hline
\end{tabular}

* Series of Chan (1962).

$\chi^{2}$ (Idf) lepromatous and non-lepromatous $\mathrm{O}: \mathrm{B}=1.5$. $\chi^{2}$ (ldf) control and leprosy $0: B=2 \cdot 4$.

From the Table it can be seen that there is no significant difference in the frequency distribution of ABO blood groups between leprosy patients and normal controls. The distribution was 40.5 and $43.5 \%$ with blood group $O ; 26.1$ and $26.0 \%$ with group $A ; 27.9$ and $25.0 \%$ with group $B ; 5.4$ and $5.5 \%$ with group AB. There was also no significant difference in the frequency distribution of ABO blood groups between 338 patients with lepromatous leprosy and 121 patients with non-lepromatous leprosy. From this investigation it is suggested that there is no association of $\mathrm{ABO}$ blood groups and leprosy. 
There was no incidence of abnormal haemoglobins among 459 Chinese subjects investigated. Among healthy Chinese in Singapore there is also a very low frequency of abnormal haemoglobins (Vella, 1962; Saha, 1970).

Of 300 male patients tested for G6PD deficiency only $5(1.5 \%)$ had G6PD deficiency as against $3.64 \%$ with G6PD deficiency in healthy males (Saha, 1969).

\section{Summary}

Four hundred and fifty-nine Chinese patients of both sexes suffering from leprosy were investigated for distribution of ABO blood groups, G6PD deficiency, and abnormal haemoglobins. There was no significant association between these genetic markers and leprosy, nor any difference of frequency distribution between lepromatous and non-lepromatous patients.

The authors gratefully acknowledge the gift of NADP and G6P from the Sigma Chemical Company, USA. Sincere thanks are due to Chan Ban Kiat and Ronald
Young of the Department of Physiology, University of Singapore, for their technical and secretarial help.

\section{REFERENCES}

Chan, K. T. (1962). The ABO blood group frequency distribution of Singapore based on blood donor sample. Singapore Medical fournal, 3, 3-15.

Hasegawa, K. (1937). Über die Blutgruppen bie Leprakranken in Japan. Lepro, 8, 769-790.

Onmichi, N. (1928). Die Bedeutung der Blutgruppen im Gebiete der Dermatologie und der Urologie. (In Japanese with a summary in German.) Okayama-Igakkai-Zasshi, 40, 1182-1191.

Kher, M. and Grover, S. (1969). Glucose-6-phosphate dehydrogenase-deficiency in leprosy. Lancet, 1, 1318-1319.

Saha, N. (1969). Incidence of G6PD deficiency in patients of three different ethnic groups suffering from pulmonary tuberculosis. fournal of Medical Genetics, 6, 292-293.

Saha, N. (1970). Prevalence of abnormal haemoglobins in pulmonary tuberculosis in three different ethnic groups. Fournal of Medical Genetics, 7, 44-46.

Saha, N. and Banerjee, B. (1968). Incidence of ABO and Rh blood groups in pulmonary tuberculosis in different ethnic groups. Fournal of Medical Genetics, 5, 306-307.

Salzano, F. M. (1967). Blood groups and Leprosy. fournal of Medical Genetics, 4, 102-106.

Sato, E. (1949). ABO blood groups and secretion especially in relation to familial leprosy. Lepro, 18, 65-68.

Vella, F. (1960). Abnormal haemoglobin variants in 10,441 Chinese subjects. Acta Haematologica, 23, 393-397.

Vogel, F. (1970). ABO blood groups and disease. American fournal of Human Genetics, 22, 464-475. 